\title{
PENGEMBANGAN BUKU CERITA ANAK BERGAMBAR BERBASIS NILAI-NILAI KEPEDULIAN BAGI PESERTA DIDIK KELAS 2 SEKOLAH DASAR
}

\author{
Rera Fenika Vindaswari, Amaliyah Ulfah \\ Universitas Ahmad Dahlan \\ rera1400005182@webmail.uad.ac.id
}

\begin{abstract}
This study aims to develop pictorial children's storybooks based on caring values and specifically aims to know, (1) steps for developing child-based pictorial children's storybooks, (2) the feasibility of caring-based children's storybooks, and (3) participant responses students of story books developed. This type of research is development research. This study uses the Borg and Gall development model which consists of five stages, namely research and information collecting, planning, developing preliminary form a product, preliminary field testing, and main product revision. The subjects of this research were 10 second grade students of Banguntapan State Elementary School with 10 childrens. Data Collecting techniques use descriptive. The data analysis technique used is descriptive. The development of pictorial children's storybooks consists of six steps, namely determining themes, making storylines/storyboards, determining characters/figures, making illustrated images, combining storybook elements, and expert validation. The results of the study showed that illustrated children's storybooks were based on values of concern for second grade students of elementary school worthy of use. Assessment according to media experts got a score of 104 (good), material expert 101 (good), and expert learning 56 (very good). The response results of students get a score of 100 (very good). Students respond that the contents of illustrated story books are interesting, stories are easy to understand, and can be used as models in attitude.
\end{abstract}

Keywords: Picture Children's Story Book, Concern Values

\begin{abstract}
ABSTRAK
Penelitian ini bertujuan mengembangkan buku cerita anak bergambar berbasis nilai-nilai kepedulian dan secara spesifik bertujuan mengetahui, (1) langkah-langkah pengembangan buku cerita anak bergambar berbasis kepedulian, (2) kelayakan buku cerita anak bergambar berbasis kepedulian, dan (3) respon peserta didik terhadap buku cerita yang dikembangkan. Jenis penelitian ini adalah penelitian pengembangan. Penelitian ini menggunakan model pengembangan Borg and Gall yang terdiri dari lima tahapan, yaitu research and information collecting, planning, develop preliminary form a product, preliminary field testing, dan main product revision. Subjek penelitian ini yaitu siswa kelas 2 SD Negeri Banguntapan sebanyak 10 anak. Teknik pengumpulan data berupa angket. Teknik analisis data yang digunakan yaitu deskriptif. Pengembangan buku cerita anak bergambar ini terdiri dari enam langkah, yaitu menentukan tema, membuat alur cerita/storyboard, penentuan karakter/tokoh, membuat ilustrasi gambar, penggabungan elemenelemen buku cerita, dan validasi ahli. Hasil penelitian menunjukkan buku cerita anak bergambar berbasis nilai-nilai kepedulian bagi peserta didik kelas 2 sekolah dasar layak digunakan. Penilaian menurut ahli media mendapat skor 104 (baik), ahli materi 101 (baik), dan ahli pembelajaran 56
\end{abstract}


(sangat baik). Hasil respon peserta didik mendapatkan skor 100 (sangat baik). Peserta didik memberikan respon bahwa isi buku cerita bergambar menarik, cerita mudah dipahami, dan dapat dijadikan model dalam bersikap.

Kata kunci: Buku Cerita Anak Bergambar, Nilai-nilai Kepedulian

\section{PENDAHULUAN}

Manusia sebagai makhluk sosial tentu tidak bisa memisahkan hidupnya dengan orang lain. Untuk itu dalam hidup bermasyarakat perlu adanya kepedulian antara manusia dengan manusia lainnya. Seperti yang dikemukakan oleh A.Tabi'in (2017) pada era sekarang ini anak-anak perlu dikenalkan bahkan di ajarkan mengenai kepedulian, agar pada suatu saat nanti anak mempunyai kepekaan terhadap orang yang membutuhkan. Penanaman kepedulian tersebut dapat dilakukan melalui berbagai cara, salah satunya melalui program pendidikan karakter di sekolah. Pendidikan karakter pada saat ini dirasa masih kurang. Hal ini dapat dilihat dari krisisnya sikap kepedulian terhadap sesama dan lingkungan sekitar. Kurangnya sikap kepedulian tersebut dapat menimbulkan perpecahan baik secara internal maupun eksternal. Faktor-faktor yang dianggap memengaruhi munculnya tindakan kurangnya sikap peduli tersebut diantaranya adalah faktor internal, faktor eksternal dan faktor pembinaan. Faktor internal adalah faktor pribadi yang ada dalam diri peserta didik, sedangkan faktor eksternal adalah faktor yang terdapat dari luar pribadi peserta didik. Faktor pembinaan yang berpengaruh pada pribadi peserta didik yang kurang baik, bisa dari orang tua/keluarga, masyarakat maupun guru di sekolah.

Berdasarkan hasil observasi yang dilakukan pada hari Jum'at, tanggal 20 Oktober 2017 pada peserta didik kelas 2 di SD Negeri Banguntapan diperoleh informasi sebagai berikut. (1) Peserta didik tidak mau meminjamkan pensil kepada temannya. (2) Peserta didik tidak membantu teman yang jatuh, tetapi mereka menertawakannya. (3) Peserta didik tidak saling berbagi makanan. (4) Peserta didik menganggu peserta didik lain ketika peserta didik tersebut sedang mengerjakan tugas. Selain di SD Negeri Banguntapan, peneliti juga melakukan observasi pada peserta didik kelas 2 di SD Negeri 1 Sekarsuli pada hari Jum'at, tanggal 20 Oktober 2017.

Adapun hasil observasi tersebut adalah sebagai berikut. (1) Peserta didik gaduh ketika pembelajaran berlangsung. (2) Ketika ada peserta didik lain yang tidak bisa mengerjakan tugas peserta didik yang lain malah mengolok-oloknya. (3) Peserta didik tidak membantu teman yang jatuh, tetapi mereka menertawakannya. Tidak hanya di SD Negeri Banguntapan dan SD Negeri 1 Sekarsuli, peneliti juga melakukan observasi pada peserta didik kelas 2 di SD Negeri 2 Jambidan pada hari Kamis, tanggal 26 Oktober 2017. Adapun hasil observasi tersebut adalah sebagai berikut. (1) Peserta didik tidak mau meminjamkan rautan kepada temannya. (2) Ketika ada peserta didik lain sedang berjalan, ada peserta didik yang sengaja memasangkan kakinya supaya peserta didik tersebut jatuh. (3) Peserta didik gaduh ketika pembelajaran berlangsung. (4) Peserta didik memanggil temannya dengan nama orang tuanya.

Selain dari observasi ke peserta didik kelas 2 sekolah dasar, peneliti juga melakukan wawancara dengan tiga guru kelas 2 sekolah dasar di SD Negeri Banguntapan, SD Negeri Sekarsuli dan SD Negeri Jambidan. Dalam wawancara tersebut, peneliti mewawancarai terkait dengan masalah dalam pengajaran nilai-nilai kepedulian pada anak. Hasil dari wawancara tersebut menunjukkan bahwa, (1) guru menganggap bahwa kepedulian sosial adalah sikap-sikap yang mendesak untuk diajarkan. (2) Guru memiliki keprihatinan terhadap kesadaran peserta didik akan rasa kepedulian, akan tetapi guru belum mempunyai cara yang tepat untuk mengatasi masalah tersebut. (3) Salah satu yang ditawarkan dalam penelitian ini adalah dengan menggunakan buku cerita anak bergambar. Guru sangat 
merespon baik dengan penggunaan buku cerita anak bergambar ini, karena dengan buku cerita anak bergambar, anak akan lebih mudah untuk memahami dan mampu mengasah imajinasi anak. Selain itu, dengan adanya buku cerita anak bergambar ini, anak bisa mengambil nilai-nilai kepedulian yang ada dari buku cerita tersebut.

Berdasarkan hasil observasi dan wawancara yang telah dipaparkan, peneliti mengambil informasi bahwa masalah yang ada di sekolah dasar yang berhubungan dengan kepedulian adalah sebagai berikut. (1) Kurangnya rasa kepedulian peserta didik terhadap sesama. (2) Guru menganggap bahwa sikap kepedulian adalah sikap yang mendesak untuk diajarkan. (3) Belum adanya buku cerita anak bergambar yang berisi tentang nilai-nilai kepedulian. (4) Mayoritas isi buku cerita yang ada di sekolah kurang bervariatif.

Permasalahan-permasalahan yang ada di sekolah dasar tersebut dapat ditangani dengan berbagai cara. Menurut Fakhrudin (2010) menjelaskan metode yang digunakan dalam penanaman moral pada anak sangatlah bervariasi, antara lain: bercerita, bernyanyi, bermain, bersajak dan karya wisata. Berdasarkan hasil penelitian yang dilakukan oleh Shufiyati (2013) tentang metode penanaman moral untuk peserta didik pendidikan anak usia dini, metode yang sering dilakukan yaitu dengan bercerita, bernyanyi dan pembiasaan dalam berperilaku. Metode yang paling banyak digunakan yaitu bercerita sebesar $63,63 \%$ dengan kriteria tinggi. Cerita anak dianggap sebagai salah satu media yang sangat efektif untuk membantu guru dan orang tua menanamkan nilai-nilai karakter pada anak. Soelistyarini (2011) mengungkapkan membaca atau mendengarkan cerita yang menarik dapat menjadi sebuah pengalaman yang menyenangkan bagi anak.

Hal inilah yang melatarbelakangi perlunya dikembangkan buku cerita anak bergambar yang memuat nilai-nilai kepedulian. Penggunaan buku cerita anak bergambar berbasis nilai kepedulian akan membuat anak belajar lebih peduli dengan sesama. Suasana belajarpun menjadi menyenangkan, sehingga peserta didik tidak merasa terbebani ataupun terpaksa dan tanpa sadar dapat menerapkan dalam kehidupan sehari-hari. Oleh karena itu peneliti akan mengadakan penelitian yang berjudul "Pengembangan Buku Cerita Anak Bergambar Berbasis Nilai-nilai Kepedulian Bagi Peserta Didik Kelas 2 Sekolah Dasar".

Adapun tujuan yang ingin dicapai dalam penelitian ini ialah: (1) untuk mengetahui langkah-langkah pengembangan buku cerita anak bergambar berbasis nilai-nilai kepedulian bagi peserta didik kelas 2 sekolah dasar. (2) Untuk mengetahui kelayakan buku cerita anak bergambar berbasis nilai-nilai kepedulian bagi peserta didik kelas 2 sekolah dasar. (3) Untuk mengetahui respon peserta didik terhadap buku cerita anak bergambar berbasis nilai-nilai kepedulian bagi peserta didik kelas 2 Sekolah Dasar.

\section{METODE PENELITIAN}

Penelitian buku cerita anak bergambar berbasis nilai-nilai kepedulian bagi peserta didik kelas 2 sekolah dasar ini merupakan jenis penelitian pengembangan atau Research and Development (R\&D). Model penelitian yang digunakan pada penelitian ini adalah model penelitian yang dikembangkan oleh Borg and Gall.

Penelitian ini mengacu pada model penelitian dan pengembangan (R\&D) menurut Borg and Gall (dalam Sugiyono, 2017) peneliti hanya melakukan pengembangan produk sampai tahap kelima yaitu revisi produk uji coba awal. Prosedur penelitian pengembangan buku cerita anak bergambar ini adalah pengumpulan informasi dan penelitian (research and information collecting), perencanaan (planning), mengembangkan bentuk awal produk (develop preliminary form a product), pengujian awal (preliminary field testing), dan revisi produk utama (main product revision).

\section{Research and Information collecting}


Penelitian dan pengumpulan informasi meliputi analisis kebutuhan, review literatur, dan penelitian dalam skala kecil. Pada tahap ini peneliti melakukan analisis kebutuhan peserta didik tentang perlu tidaknya pengembangan buku cerita anak bergambar berbasis nilai-nilai kepedulian bagi peserta didik kelas 2 sekolah dasar. Pengumpulan berbagai informasi yang dapat digunakan sebagai bahan perencanaan pembuatan produk untuk mengatasi masalah yang telah ditemukan. Beberapa masalah tersebut diantaranya adalah belum adanya buku cerita anak bergambar berbasis nilai-nilai kepedulian bagi peserta didik kelas 2 sekolah dasar.

\section{Planning}

Setelah melakukan analisis kebutuhan, riview literatur dan penelitian dalam skala kecil, selanjutnya melakukan perencanaan yang meliputi pendefinisian keterampilan yang harus dipelajari, perumusan tujuan dan uji coba kelayakan (dalam skala kecil). Pada tahap ini, perlu dikumpulkan berbagai informasi yang dapat digunakan sebagai bahan perencanaan yaitu dengan cara melakukan observasi dan wawancara di berbagai sekolah dasar.

\section{Develop Preliminary Form a Product}

Dalam penelitian ini, untuk pengembangan produk awal yang meliputi penyiapan materi, prosedur/penyusunan buku, desain produk dan instrumen evaluasi. Desain produk berupa buku cerita anak bergambar berbasis nilai-nilai kepedulian bagi peserta didik kelas 2 sekolah dasar. Pada tahap ini peneliti mulai merancang dan membuat desain produk berdasarkan ide yang telah dikumpulkan. Buku cerita anak bergambar yang dikembangkan dalam penelitian ini fokus pada penanaman nilai-nilai kepedulian sosial pada anak. Sebelum dilakukan validasi, terlebih dahulu produk ditinjau oleh dosen pembimbing untuk diberikan masukan dan saran untuk produk yang dikembangkan.

Pada tahap desain produk, peneliti melakukan beberapa langkah sebagai berikut:

a. Menentukan tema, membuat membuat alur cerita/storyboard, menentukan karakter/tokoh dalam buku cerita anak bergambar yang akan dikembangkan.

b. Mendesain ilustrasi dan menggabungkan elemen-elemen buku cerita, kemudian dikonsultasikan terlebih dahulu dengan dosen pembimbing dan divalidasikan oleh ahli materi, ahli media, dan ahli pembelajaran.

c. Menyusun instrumen penelitian yang meliputi angket uji kelayakan buku cerita anak bergambar oleh ahli materi, ahli media, ahli pembelajaran, penilaian guru dan respon peserta didik.

\section{Preliminary Field Testing}

Setelah melakukan pengembangan produk awal mendesain buku cerita anak bergambar, langkah berikutnya yang dilakukan oleh peneliti adalah melakukan uji coba lapangan buku cerita anak bergambar. Dalam melakukan uji coba lapangan buku cerita anak bergambar, peneliti mengujikan terhadap kelompok kecil yang terdiri 6-12 peserta didik di SD Negeri Banguntapan. Uji coba lapangan dilakukan dengan memberikan angket kepada peserta didik dan guru kelas 2 sekolah dasar di SD Negeri Banguntapan.

\section{Main Product Revision}

Revisi produk bertujuan untuk memperbaiki kekurangan pada produk buku cerita anak bergambar yang telah di uji cobakan pada beberapa peserta didik kelas 2 sekolah dasar di SD Negeri Banguntapan. Revisi produk dilakukan berdasarkan pada analisis dan hasil uji coba produk serta kritik dan saran yang disampaikan oleh peserta didik dalam uji coba produk.

Uji Coba Produk

Desain Uji Coba 
Uji coba produk dilakukan untuk mengetahui apakah buku cerita anak bergambar berbasis nilai-nilai kepedulian bagi peserta didik kelas 2 sekolah dasar layak digunakan atau tidak. Selain itu uji coba produk ini dilakukan untuk menanamkan nilai-nilai kepedulian pada peserta didik kelas 2 sekolah dasar, dengan mempraktikan secara langsung di lapangan. Adapun tahap uji coba pada penelitian ini adalah sebagi berikut:

1. Uji coba ahli dilakukan oleh ahli dalam bidangnya, yaitu ahli media, ahli materi, dan ahli pembelajaran.

2. Uji coba produk ini diujikan dalam kelompok kecil yang dilakukan pada 6-12 peserta didik kelas 2 di SD Negeri Banguntapan. Uji coba ini dilakukan untuk mengetahui kelayakan buku cerita anak berbasis nilai-nilai kepedulian bagi peserta didik kelas 2 sekolah dasar.

Subjek uji coba pengembangan buku cerita anak bergambar berbasis nilai-nilai kepedulian bagi peserta didik kelas 2 sekolah dasar 10 peserta didik kelas 2 di SD Negeri Banguntapan, Kecamatan Banguntapan, Kabupaten Bantul, Yogyakarta.

Jenis data yang diperoleh dalam penelitian pengembangan yang berjudul pengembangan buku cerita anak bergambar berbasis nilai-nilai kepedulian bagi peserta didik kelas 2 sekolah dasar, yaitu data kualitatif dan kuantitatif mengenai prosedur pengembangan serta tingkat kelayakan produk sesuai dengan pengembangan yang ditentukan.

Instrumen pengumpulan data yang digunakan oleh peneliti adalah observasi (pengamatan), wawancara, angket dan dokumentasi. Lembar observasi digunakan untuk melakukan pengamatan secara langsung. Observasi yang dilakukan adalah observasi aktivitas peserta didik kelas 2 sekolah dasar pada saat di sekolah. Wawancara digunakan untuk menemukan permasalahan dan potensi yang harus diteliti, tetapi juga apabila peneliti ingin mengetahui hal-hal dari responden yang lebih mendalam. Angket atau kuesioner merupakan teknik pengumpulan data yang digunakan untuk memperoleh informasi dari responden dengan cara memberikan seperangkat pertanyaan tertulis kepada responden. Skala pedoman observasi untuk para ahli dan guru kelas pada penelitian pengembangan ini adalah skala Likert. Skala pedoman observasi untuk peserta didik kelas 2 pada penelitian pengembangan ini adalah skala Guttmen. Dokumentasi dilakukan dengan mengambil foto untuk data pendukung pengamatan karakter kepedulian pada siswa.

Teknik analisis data yang digunakan dalam penelitian ini yaitu menggunakan teknik analisis data kualitatif dan data kuantitatif.

1. Data kualitatif berupa nilai setiap kriteria penilaian kuesioner yang dijabarkan menjadi sangat baik, baik, cukup baik, kurang baik, dan sangat kurang baik serta hasil angket peserta didik yang berupa ya dan tidak.

2. Data kuantitatif yang berupa skor penilaian menggunakan YA (1) dan TIDAK (0) dan skala Likert dengan 5 pilihan dalam Widoyoko (2009) yaitu sangat baik $=5$, baik $=4$, cukup baik $=3$, kurang baik $=2$, dan sangat kurang baik $=1$.

Data diperoleh dengan menghitung skor setiap kriteria yang dihitung dari penilaian ahli media, ahli materi, ahli pembelajaran, dan guru. Penjabaran dari analisis kedua data tersebut menggunakan langkah-langkah berikut:

1. Mentabulasi semua data dengan menjumlahkan skor yang diperoleh dari para validator dan guru untuk setiap komponen, dari butir penilaian instrumen penelitian.

2. Mengubah jumlah skor menjadi nilai dengan kriteria

Pedoman pengubahan data kuantitatif menjadi data kualitatif menurut Sukardjo (2005) dipaparkan dalam tabel berikut. 
Tabel 1. Konversi Skor Menjadi

Skala Lima
\begin{tabular}{|l|l|c|l|}
\hline No & \multicolumn{1}{|c}{ Skor Peserta didik } & Nilai & \multicolumn{1}{|c|}{ Kriteria } \\
\hline 1 & $\mathrm{X}>\mathrm{Mi}_{i}+1,8 \mathrm{SB}_{i}$ & $\mathrm{~A}$ & Sangat baik \\
\hline 2 & $\mathrm{Mi}_{i}+0,6 \mathrm{SB}_{i}<\mathrm{X} \leq \mathrm{Mi}_{1}+1,8 \mathrm{Sbi}$ & $\mathrm{B}$ & Baik \\
\hline 3 & $\mathrm{Mi}_{i}-0,6 \mathrm{SB}_{i}<\mathrm{X} \leq \mathrm{Mi}_{i}+0,6 \mathrm{Sbi}$ & $\mathrm{C}$ & Cukup baik \\
\hline 4 & $\mathrm{Mi}_{i}-1,8 \mathrm{SB}_{i}<\mathrm{X} \leq \mathrm{Mi}_{i}-0,6 \mathrm{Sbi}$ & $\mathrm{D}$ & Kurang baik \\
\hline 5 & $\mathrm{X} \leq \mathrm{Mi}_{i}-1,8 \mathrm{SB}_{i}$ & E & Sangat kurang baik \\
\hline
\end{tabular}

Keterangan:

$\mathrm{X} \quad=$ Skor aktual

$\mathrm{Mi} \quad=$ Mean ideal $\left(1 / 2\left(\mathrm{X}_{\mathrm{mak}}+\mathrm{X}_{\min }\right)\right.$

Sbi $=$ Simpangan baku ideal $=1 / 6\left(X_{\text {mak }}-X_{\text {min }}\right)$

Media buku cerita anak bergambar berbasis nilai-nilai kepedulian dapat dikatakan layak apabila skor yang diperoleh mendapat kategori baik maupun sangat baik dari validator, guru dan peserta didik. Maka, pada kategori pernyataan rumus di atas akan dapat diketahui kelayakan dan kualitas media buku cerita bergambar berbasis nilai-nilai kepedulian bagi peserta didik kelas 2 sekolah dasar. Kemudian untuk menghitung hasil penilaian skor dari peserta didik menggunakan ya (1) dan tidak (0) menggunakan rumus dalam Sudjana (2017) yaitu:

$$
P=\frac{f}{N} \times 100
$$

Keterangan:

$\mathrm{P}=$ Nilai yang dicari

$\mathrm{F}=$ Jumlah skor jawaban YA

$\mathrm{N}=$ Jumlah peserta didik

$100=$ Nilai tetap

3. Setelah diperoleh persentase dari rumus di atas, kemudian peneliti menafsirkan ke dalam kriteria skala lima menurut Arikunto (2015:281) sebagai berikut:

$$
\begin{array}{ll}
80-100 & =\text { sangat baik } \\
66-79 & =\text { baik } \\
56-65 & =\text { cukup } \\
40-55 & =\text { kurang } \\
30-39 & =\text { sangat kurang }
\end{array}
$$

Berdasarkan beberapa rumus di atas pengembangan buku cerita dikatakan layak bagi peserta didik jika data atau nilai yang diperoleh dari ahli media, ahli materi, ahli pembelajaran, guru dan respon peserta didik mendapat kategori sangat baik atau baik.

\section{HASIL DAN PEMBAHASAN}

Data uji coba hasil penelitian ini berdasarkan tahapan model penelitian pengembangan Borg and Gall yang peneliti batasi hanya sampai tahap revisi produk awal (main product revision). Selain itu data yang diperoleh dari hasil penelitian ini adalah data kualitatif dan kuantitatif. Data kualitatif diperoleh dari tanggapan, komentar serta masukan dari validasi ahli, guru kelas, dan respon peserta didik mengenai buku cerita anak bergambar. Sedangkan data kuantitatif diperoleh dari hasil penilaian lembar observasi oleh ahli media, ahli materi dan ahli pembelajaran, serta respon dari guru kelas dan peserta didik terhadap kelayakan buku cerita anak bergambar. Data uji coba hasil penelitian pengembangan berdasarkan model pengembangan Borg and Goll adalah sebagai berikut: 


\section{Research and Information collecting}

Tahap awal dalam penelitian ini adalah pengumpulan informasi dan penelitian, yang meliputi tinjauan literature, observasi, dan analisis kebutuhan. Pada tahap ini peneliti melakukan analisis kebutuhan peserta didik mengenai perlu tidaknya pengembangan media buku cerita anak bergambar.

Berdasarkan hasil observasi yang dilakukan oleh peneliti pada tanggal 20 Oktober 2017 di SD Negeri Banguntapan didapatkan kondisi nyata di lapangan bahwa guru dan pihak sekolah belum memiliki strategi dalam menanamkan nilai-nilai kepedulian pada peserta didik, adanya perilaku kurang peduli terhadap sesama seperti peserta didik tidak mau meminjami pensil kepada temannya, peserta didik tidak mau membagi makanan kepada temannya, ketika ada peserta didik lain yang tidak bisa mengerjakan tugas peserta didik yang lain malah mengolok-oloknya, ketika ada teman yang jatuh mereka menertawakannya, dan membuat suasana gaduh ketika pembelajaran sedang berlangsung. Selain itu juga, belum ada media yang bisa digunakan guru dalam menanamkan nilai-nilai kepedulian.

Upaya penanaman nilai-nilai kepedulian kepada peserta didik membutuhkan cara yang praktis dan menarik, karena karakteristik peserta didik sekolah dasar akan lebih tertarik apabila melihat gambar-gambar dengan kolaborasi warna yang menarik. Namun, di SD Negeri Banguntapan Bantul Yogyakarta ini, guru belum menggunakan media yang menarik untuk menanamkan nilai-nilai kepedulian kepada peserta didik, oleh karenanya peneliti memiliki ide untuk mengembangkan media buku cerita anak bergambar berbasis nilai-nilai kepedulian yang dikreasikan dengan gambar dan warna yang menarik.

\section{Planning}

Setelah melakukan tinjauan literature dan analisis kebutuhan peneliti melakukan perencanaan yang meliputi pendefinisian keterampilan yang harus dipelajari, perumusan tujuan, dan uji kelayakan skala kecil. Buku cerita anak bergambar bertujuan untuk membantu peserta didik dalam menumbuhkan nilai-nilai kepedulian, dengan buku cerita anak bergambar diharapkan agar nilai-nilai kepedulian yang terkadung didalamnya dapat tertanamkan dalam diri peserta didik sejak dini.

\section{Develop Preliminary Form a Product}

Pada tahap ini peneliti mulai merancang dan membuat desain produk awal. Berikut ini adalah tahapan dalam pengembangan buku cerita.

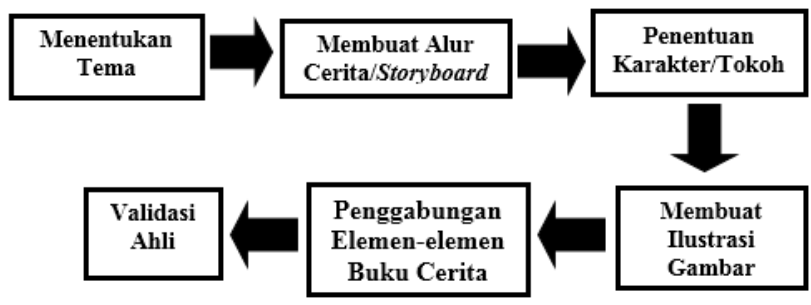

\section{Gambar 1. Tahapan dalam Pengembangan Buku Cerita}

Adapun penjelasan dari gambar tahapan dalam pengembangan buku cerita anak bergambar adalah sebagai berikut.

a. Menentukan Tema

Pada tahap menentukan tema, penentuan tema yang dikembangkan disesuaikan dengan kurikulum yang digunakan yaitu kurikulum 2013. Tema yang sesuai yaitu tema 1 subtema 3 Hidup Rukun di Sekolah yang berisi mata pelajaran Bahasa Indonesia, PPKn, 
dan SBDP. KD Bahasa Indonesia 3.5 Mengenal teks permintaan maaf tentang sikap hidup rukun dalam kemajemukan keluarga dan teman dalam bahasa Indonesia lisan dan tulis yang dapat diisi dengan kosakata bahasa daerah untuk membantu pemahaman. KD PPKn 3.3 Memahami makna keberagaman karakteristik individu di rumah dan di sekolah, dan KD SBDP 4.1 Menggambar ekspresi dengan mengolah garis, warna, bentuk dan tekstur berdasarkan hasil pengamatan di lingkungan sekitar. Pemilihan materi tersebut disesuaikan dengan materi di kelas 2 sendiri dan materi tersebut digunakan sebagai bahan pembuatan teks cerita dalam media buku cerita anak bergambar berbasis nilai-nilai kepedulian.

b. Membuat Alur Cerita/Storyboard

Alur cerita dimulai dari karakter tokoh seorang anak perempuan yang rajin dan akan pergi ke sekolah. Kemudian dilanjutkan dengan adanya konflik dalam perjalanan ke sekolah bertemu dengan seorang kakek yang terkena musibah dan segera membutuhkan pertolongan. Dalam konflik inilah nilai-nilai kepedulian dimasukkan ketika tokoh dihadapkan pada langkah apa yang harus diambil untuk mengatasi masalah yang ada.

c. Penentuan Karakter/Tokoh

Dalam pengembangan buku cerita anak bergambar ini, peneliti menentukan karakter/tokoh yaitu Elma sebagai tokoh utama, Ibu Elma, Kakek tua dan Ibu Tuti sebagai tokoh protagonis. Pembuatan karakter/tokoh ini menyesuaikan dengan peran setiap tokoh. Elma adalah karakter utama yang ada dalam buku cerita anak bergambar. Ibu Elma merupakan tokoh protagonis yang selalu menyayangi Elma. Kakek tua merupakan tokoh protagonis yang begitu baik dengan Elma, dan Ibu Tuti juga merupakan tokoh protagonis yang pemaaf.

d. Membuat Ilustrasi Gambar

Tahap ini adalah tahap dimana sebuah narasi divisualisasikan dalam bentuk gambar dengan ukuran kertas $23 \mathrm{~cm} \times 19 \mathrm{~cm}$. Tahap awal untuk membuat ilustrasi gambar adalah dengan mensketsa ilustrasi yang menggunakan alat dan bahan pensil, penghapus dan drawing pen. Setelah ilustrasi gambar selesai disketsa, kemudian hasil sketsa tersebut di scan. Langkah selanjutnya yaitu gambar mulai diwarna dengan menggunakan aplikasi photoshop.

1) Ilustrasi Sampul Buku Cerita Anak Bergambar

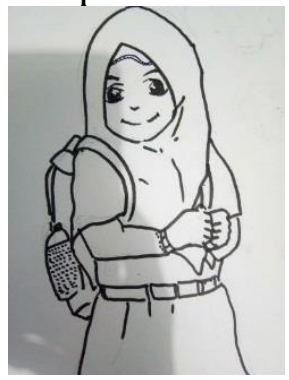

\section{Gambar 2. Ilustrasi Sampul Buku}

2) Ilustrasi Isi Buku Cerita Anak Bergambar

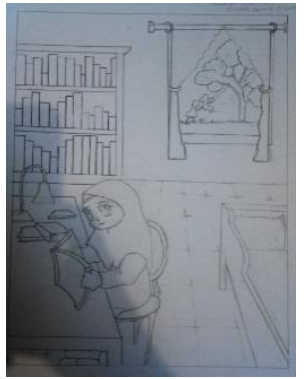

Gambar 3. Ilustrasi Isi Buku Cerita 
a. Penggabungan Elemen-elemen Buku Cerita

Penggabungan elemen-elemen buku cerita adalah proses penggabungan teks/narasi dengan gambar ilustrasi yang kemudian dilanjutkan dengan percetakan buku cerita anak bergambar. Proses ini dilakukan dengan pertimbangan layout yang sesuai agar teks/narasi tidak mengganggu gambar ilustrasi atau sebaliknya.

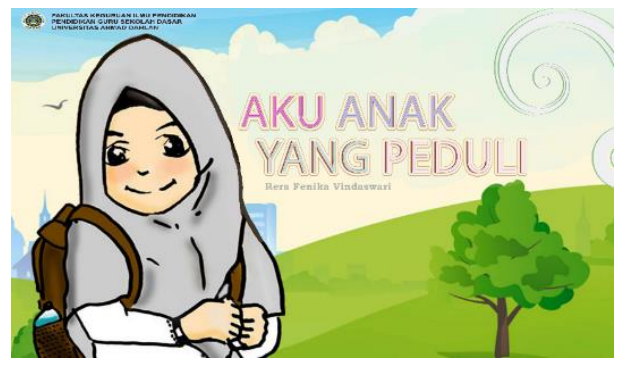

Gambar 4. Hasil Penggabungan Elemen-elemen Sampul Buku Cerita

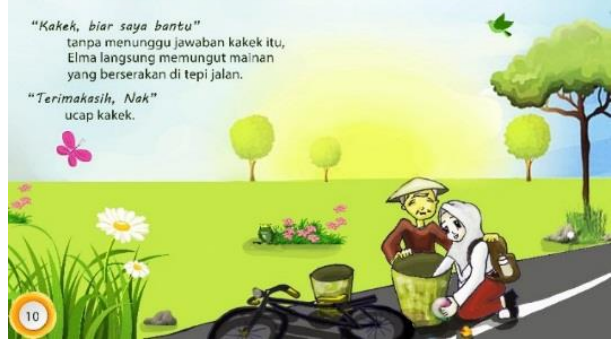

Gambar 5. Hasil Penggabungan Elemen-elemen Isi Buku Cerita

b. Validasi Ahli

Setelah buku cerita anak bergambar dicetak, buku cerita divalidasikan oleh para ahli yaitu ahli media, ahli materi, dan ahli pembelajaran. Hal ini bertujuan untuk mengetahui penilaian para ahli terhadap media yang dikembangkan.

1) Validasi ahli media

Penilaian dari validasi ahli media menunjukkan jumlah skor 104 dari skor maksimal 130, sehingga mendapat nilai $\mathrm{B}$ dan mendapat penilaian dengan kategori Baik. Buku cerita anak bergambar dikatakan baik karena menurut ahli media, bahasa yang digunakan sudah sesuai dengan tingkat perkembangan peserta didik. Relevansi antara teks cerita dengan ilustrasi gambar baik. Kesesuaian cerita dengan materi pembelajaran dan ilustrasi gambar. Kejelasan bahasa yang digunakan dalam cerita. Desain dan warna sampul buku cerita menarik.

Selain itu, alur cerita sudah sesuai dengan perkembangan peserta didik. Kemudahan dalam memahami alur isi cerita sangat baik. Ketepatan ukuran buku cerita anak bergambar sangat baik. Buku cerita bersifat fleksibel dan dapat menambah motivasi belajar peserta didik. Penggunaan buku cerita bergambar yang bagus itu memang dapat berpengaruh terhadap peserta didik, seperti yang diungkapkan oleh Sutherland (dalam Faizah, 2009:252) buku cerita bergambar yang baik yaitu buku cerita bersifat ringkas dan langsung, buku cerita bergambar berisi konsep-konsep yang berseri, konsep yang ditulis dapat difahami oleh anakanak, gaya penulisannya sederhana, terdapat ilustrasi yang menarik yang melengkapi teks.

2) Validasi ahli materi

Penilaian dari validasi ahli materi menunjukkan jumlah skor 101 dari skor maksimal 135, sehingga mendapat penilaian dengan kategori Baik. Buku cerita anak bergambar dikatakan baik karena menurut ahli materi kesesuaian materi 
dengan indikator sudah sesuai. Kelengkapan materi yang disajikan dan sistematika materi baik. Materi sudah sesuai dengan perkembangan peserta didik. Isi materi dapat merangsang kepekaan sosial dan merangsang kemampuan berpikir sistematik peserta didik. Selain itu, menurut ahli materi buku cerita anak bergambar yang dikembangkan dapat membantu proses belajar, materi yang disajikan menjadikan proses pembelajaran menyenangkan. Materi dalam buku cerita anak bergambar dapat merangsang kepedulian sosial peserta didik. Bahasa yang digunakan dalam buku cerita mampu menunjang keterampilan alur berfikir peserta didik.

3) Validasi ahli pembelajaran

Penilaian dari validasi ahli pembelajaran menunjukkan jumlah skor 56 dari skor maksimal 60, sehingga mendapat penilaian dengan kategori Sangat Baik. Buku cerita anak bergambar dikatakan sangat baik karena menurut ahli pembelajaran media yang dikembangkan sudah sesuai dengan tujuan dan langkahlangkah pembelajaran. Kesesuaian penilaian afektif, kognitif dan psikomotor dengan pengembangan media buku cerita anak bergambar. Media buku cerita anak bergambar dapat digunakan dalam proses pembelajaran.

\section{Preliminary Field Testing}

Uji coba produk dilakukan pada peserta didik kelas 2 di SD N Banguntapan pada hari Selasa, 07 Agustus 2018. Tata cara uji coba produk yang dilakukan yaitu diawali dengan penjelasan materi tentang keberagaman karakteristik individu, kemudian peneliti membagi peserta didik ke dalam 5 kelompok dan masing-masing kelompok dibagikan satu buku cerita anak bergambar. Selama uji coba produk berlangsung, para peserta didik sangat antusias untuk membaca buku cerita tersebut. Setelah peserta didik membaca buku cerita anak bergambar, peneliti melakukan tanya jawab dengan peserta didik terkait dengan isi buku cerita yang dibagikan. Selanjutnya, peneliti membagikan instrumen/angket untuk diisi oleh peserta didik. Instrumen penilaian/angket ini bertujuan untuk mengetahui respon peserta didik terhadap buku cerita anak bergambar yang telah dikembangkan.

\section{a. Validasi oleh guru}

Penilaian dari guru kelas 2 menunjukkan jumlah skor 85 dari skor maksimal 100, sehingga mendapat nilai A dan mendapat penilaian dengan kategori Sangat Baik. Buku cerita anak bergambar dikatakan sangat baik karena menurut guru materi dalam media sudah sesuai dengan kompetensi dasar dan indikator. Isi cerita sudah sesuai dengan materi pembelajaran. Ilustrasi yang disajikan sesuai dengan tingkat perkembangan peserta didik. Alur isi buku cerita mudah untuk dipahami. Buku cerita dapat mendorong minat belajar dan memberikan motivasi belajar bagi peserta didik.

b. Respon peserta didik

Penilaian media buku cerita anak bergambar berbasis nilai-nilai kepedulian bagi peserta didik kelas 2 sekolah dasar sejumlah 10 peserta didik SD Negeri Banguntapan, yakni menunjukkan skor 100 dari skor maksimal 100. Apabila ditafsirkan ke dalam kriteria skala lima menurut Arikunto (2015:281) termasuk dalam kategori "Sangat Baik". respon terhadap buku cerita anak bergambar yang dikembangakan dari 10 peserta didik positif. Mereka menyebutkan bahwa buku cerita anak bergambar yang dikembangkan bagus, sampul, isi, dan warna buku cerita menarik. Kata-kata dalam buku cerita mudah dipahami. Gambar sesuai dengan alur dalam cerita. Tulisan dalam buku cerita mudah dibaca. Buku cerita 
anak bergambar dapat memberikan semangat dalam belajar dan peserta didik juga senang menggunakan buku cerita untuk belajar.

\section{Main Product Revision}

Revisi produk bertujuan untuk memperbaiki kekurangan pada produk media buku cerita anak bergambar berbasis nilai-nilai kepedulian yang telah divalidasi oleh para ahli, penilaian oleh guru dan di uji cobakan pada 10 peserta didik kelas 2 SD Negeri Banguntapan. Revisi produk dilakukan berdasarkan pada analisis dan masukan yang diberikan oleh para ahli, guru dan uji coba (terbatas) yang telah dilakukan.

Pada tahap ini, peneliti hanya merevisi dari kritik dan saran para ahli karena masih ada beberapa yang perlu diperbaiki dari media yang dikembangkan sebelum diuji cobakan langsung kepada peserta didik dan dinilaikan juga oleh guru kelas 2 . Hasil angket dari guru dan peserta didik semuanya memberikan respon yang baik dan sudah baik juga respon terhadap media yang dikembangkan, sehingga tidak ada revisi media yang didapat dari guru dan peserta didik.

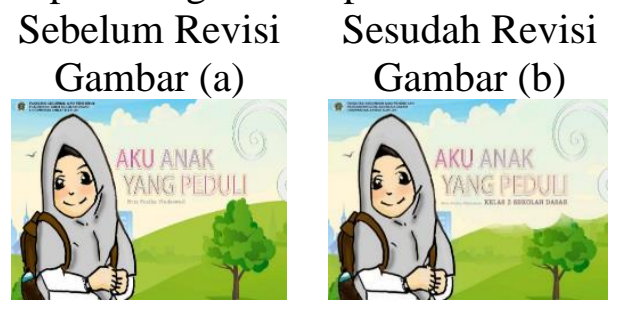

\section{Gambar 6. Perbaikan pada Sampul Buku Cerita}

Pada gambar (a) merupakan tampilan sampul buku cerita anak bergambar sebelum dilakukan revisi, sampul buku cerita dinilai masih kurang karena belum dicantumkan spesifikasi kelasnya. Setelah dilakukan revisi gambar pada (b) sampul buku dinilai lebih jelas dan spesifik.

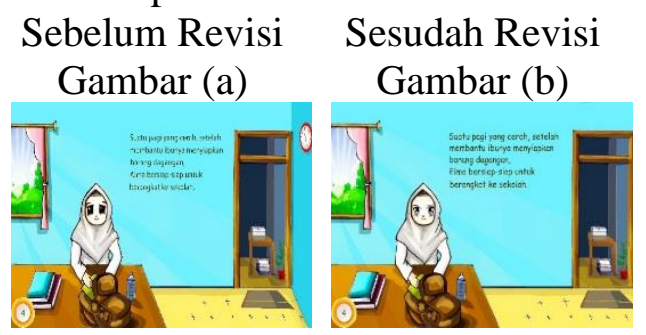

\section{Gambar 7. Perbaikan pada}

\section{Bentuk Mata}

Pada gambar (a) merupakan tampilan mata yang berbentuk kotak sebelum dilakukan revisi, tampilan mata dinilai kurang pas karena berbentuk kotak. Setelah dilakukan revisi gambar pada (b) tampilan mata dinilai lebih sesuai.

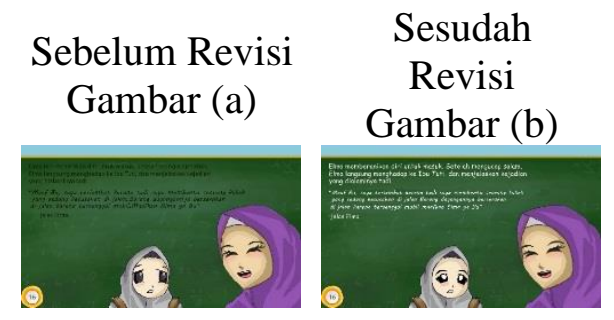

Gambar 8. Perbaikan Warna Font 
Pada gambar (a) merupakan tampilan font yang berwarna hitam sebelum dilakukan revisi, tampilan font warna hitam dinilai kurang jelas terbaca karena backgroundnya sudah berwarna gelap. Setelah dilakukan revisi gambar pada (b) tampilan warna font dinilai sudah jelas dibaca.

Produk akhir dari pengembangan ini adalah sebuah buku cerita anak bergambar berbasis nilai- nilai kepedulian bagi peserta didik kelas 2 sekolah dasar.

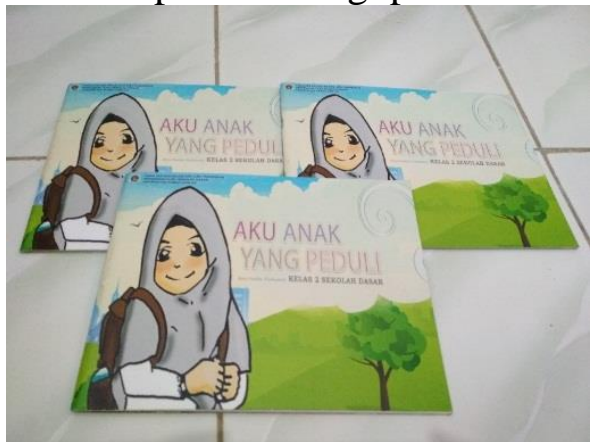

\section{Gambar 9. Produk Akhir Buku Cerita Anak Bergambar Berbasis Nilai-nilai Kepedulian}

Buku cerita anak bergambar memiliki spesifikasi ukuran kertas $23 \mathrm{~cm} \times 19 \mathrm{~cm}$. Buku cerita yang dikembangkan memiliki 28 halaman full color. Kertas yang digunakan dalam pembuatan sampul buku berjenis AC 310, sedangkan isi buku cerita menggunakan kertas MP 150. Bahasa yang digunakan dalam cerita juga mudah untuk dipahami peserta didik. Buku cerita yang dikembangkan memuat cerita seorang anak yang memiliki sifat peduli sosial, karena walaupun ia sedang terburu-buru ia masih menyempatkan waktunya untuk membantu seorang kakek yang sedang kesusahan di jalan.

\section{SIMPULAN} berikut:

Berdasarkan hasil penelitian dan pembahasan, dapat ditarik kesimpulan sebagai

1. Penelitian pengembangan ini mengacu pada model penelitian yang dikembangkan oleh Borg and Gall yang terdiri dari 10 tahap. Akan tetapi peneliti hanya mengembangkan sampai pada tahap ke 5 yaitu main product revision. Hal tersebut dikarenakan keterbatasan waktu dan biaya peneliti. Langkah-langkah untuk mengembangkan buku cerita anak bergambar berbasis nilai-nilai kepedulian ini terdiri dari 6 langkah, yaitu menentukan tema, membuat alur cerita/storyboard, penentuan karakter/tokoh, membuuat ilustrasi gambar, penggabungan elemen-elemen buku cerita, dan validasi ahli.

2. Media buku cerita anak bergambar yang dikembangkan layak menurut ahli media dengan skor 104 dari skor maksimal 130, sehingga memperoleh kategori Baik. Menurut ahli materi mendapat skor 101 dari skor maksimal 135, sehingga memperoleh kategori Baik. Sedangkan menurut ahli pembelajaran mendapat skor 56 dari skor maksimal 60, sehingga memperoleh kategori Sangat Baik.

Penilaian guru diperoleh skor dari pengisian angket guru terhadap penggunaan media buku cerita anak bergambar mendapatkan skor 85 dari skor maksimal 100 dengan kategori Sangat Baik. Pada tahap uji terbatas (kelompok kecil), hasil penilaian angket respon peserta didik seluruhnya mendapat skor 100 dari skor maksimal 100 dengan kategori Sangat Baik. Hasil penelitian mengidentifikasikan bahwa media buku cerita anak bergambar berbasis nilai-nilai kepedulian memiliki kelayakan yang Baik digunakan dalam pembelajaran dan penanaman karakter kepedulian. 
3. Respon peserta didik terhadap buku cerita anak bergambar yang dikembangkan sangat baik. Peserta didik menilai bahwa isi cerita menarik, mudah dipahami, gambar sesuai dengan alur cerita, dan dapat memberikan semangat dalam belajar.

\section{DAFTAR PUSTAKA}

Arikunto, Suharsimi. 2015. Dasar - Dasar Evaluasi Pendidikan Edisi 2. Jakarta: Bumi Aksara.

Efta Shufiyati. 2013. "Keefektifan Metode Penanaman Moral Bermuatan Pendidikan Karakter Bagi Siswa Pendidikan Anak Usia Dini Di Kota Semarang”. Skripsi. Fakultas Ilmu Sosial Universitas Negeri Semarang.

Faizah, Umi. 2009. "Keefektifan Cerita Bergambar untuk Pendidikan Nilai dan Keterampilan Berbahasa Dalam Pembelajaran Bahasa Indonesia”. Cakrawala Pendidikan. Tahun 28, No 3.

Fakhrudin, Asef Umar. 2010. Sukses Menjadi Guru TK-PAUD. Yogyakarta: Bening.

Sugiyono. 2017. Metode Penelitian \& Pengembangan Research and Development. Bandung: Alfabeta.

Sukardjo. (2005). Evaluasi Pembelajaran. Diktat mata kuliah evaluasi pembelajaran. Prodi TP PPs UNY. Tidak diterbitkan.

Tabi'in,A. 2017. Menumbuhkan Sikap Peduli Pada Anak Melalui Interaksi Kegiatan Sosial. Journal of Social Science Teaching. Vol. 1 no. 1.

Titien Diah Soelistyarini. "Cerita Anak dan Pembentukan Karakter". Disampaikan dalam Lokakarya Pembentukan Karakter Bangsa Melalui Sastra Anak pada tanggal 22 Oktober 2011.

Widoyoko, Eko Putro. 2009. Evaluasi Program Pembelajaran Panduan Praktis Bagi Pendidik dan Calon Pendidik. Yogyakarta: Pusat Pelajar. 